\title{
A Design of CBI-Embedded Course System in College English Teaching A Case Study of Economics Major
}

\author{
Chen $\mathrm{Li}$ \\ School of Foreign Languages, Wuhan Polytechnic University, Wuhan, Hubei, China \\ 99759484@qq.com
}

Keywords: Content-Based Instruction(CBI); Course System; College English Teaching

\begin{abstract}
The ultimate goal of College English teaching is to produce bilinguals with specialized knowledge in technical, scientific and other specialty related fields, who can use English to communicate with native speakers, especially specialists and professionals. However, the present foundation stage curricula especially in most of the ordinary colleges and universities in which knowledge of the English language dominates the main role can hardly prepare students for the demanding and difficult bilingual education. In this paper endeavors are made to provide a way to solve the problem mentioned above by offering an case study of Economics Major in an ordinary university. This paper studies how CBI can be embedded into the existing College English course systems and how CBI can be enacted in a language classroom by giving solutions to problems CBI has encountered.
\end{abstract}

\section{Introduction}

Content-Based Instruction (CBI), distinguished by its dual commitment to language and content learning, has gained worldwide popularity in contemporary language teaching approaches.

CBI has been implemented in many different settings used as the instructional principles in ESL/EFL courses of many different kinds. Brinton, Snow, and Wesche (2003) specify the meaning of $\mathrm{CBI}$ as "the concurrent study of language and subject matter, with the form and sequence of language presentation dictated by content material".

Present-day examples of CBI include university foreign language programs which have been increasingly shown very effective. It is widely accepted that language skills are most effectively learned in context and emerge most naturally in purposeful study. In this sense, CBI can be defined as a foreign language teaching approach that integrates content or information with language instruction to facilitate both language acquisition and content learning.

\section{The Design of CBI-Embedded Course System}

The goal of the CBI course is to integrate the language with academic knowledge of their specialty and to help students to be linguistically and academically ready for bilingual instruction or future academic learning. In this paper CBI-Embedded course system of Economics Major is designed to serve as an example. Therefore the open course, Financial Markets offered by Yale University, is chosen.

Language and content leaning are combined in this course. In order to develop a CBI course appropriate to students' cognitive level and interests, the course objectives

and syllabus were co-conducted with the Chinese specialty teacher who has experience in teaching Financial Markets in Chinese.

Co-planning the Course Objectives. It strives to offer basic understanding of the theory of finance and its relation to the history, strengths and imperfections of such institutions as banking, insurance securities, futures, and other derivatives markets, and the future of these institutions over the next century. On the other hand, great emphasis is put on equipping students with listening skills of how to comprehend lecture better with the help of rhetorical patterns.

Co-planning the Course Syllabus. As the CBI course is carried out every two weeks, the original syllabus of Financial Market has to be modified to suit the CBI timetable. By consulting the specialty teacher, eight topics (see Table 1) are selected based on the consideration of Students' interest and 
correlation between topics. Then the language teacher needs to begin the second time selection of what content to be included in each lecture by adapting 75-minute lecture to 100-minute CBI lesson. Since class activities will take time, usually a 100-minute can only cover 50-minute lecture, the omitting part of the lecture will either be explained briefly or assigned as homework.

Table 1 Syllabus with Dual Curriculum Goals

\begin{tabular}{|l|l|l|}
\hline & Subject Matter & Listening Skills \\
\hline Unit One & $\begin{array}{l}\text { Finance Powerful and } \\
\text { Insurance Forces in Economy } \\
\text { and Society }\end{array}$ & $\begin{array}{l}\text { Introduction, emphasizing, shifting } \\
\text { and closing of a topic }\end{array}$ \\
\hline Unit Two & $\begin{array}{l}\text { The Universal Principle of } \\
\text { and the Hedging of Risks }\end{array}$ & $\begin{array}{l}\text { Highlighting and } \\
\text { certain information paraphrasing } \\
\text { Drawing question attention by } \\
\text { asking }\end{array}$ \\
\hline Unit Three & $\begin{array}{l}\text { Portfolio Diversification and } \\
\text { Supporting Financial } \\
\text { Institutions }\end{array}$ & $\begin{array}{l}\text { Giving framework of the lecture } \\
\text { Summarizing }\end{array}$ \\
\hline Unit Four & $\begin{array}{l}\text { Behavioral Finance: The Role } \\
\text { of Psychology }\end{array}$ & Definition and Classification \\
\hline Unit Five & $\begin{array}{l}\text { Debt Markets: Term Structure } \\
\text { Stocks }\end{array}$ & $\begin{array}{l}\text { Casual Analysis } \\
\text { Hypossing and coming back }\end{array}$ \\
\hline Unit Seven & $\begin{array}{l}\text { Real Estate Finance and Its } \\
\text { Vulnerability to Crisis }\end{array}$ & Casual Analysis \\
\hline Unit Eight & $\begin{array}{l}\text { Stock Futures Index, Oil and } \\
\text { Other Markets }\end{array}$ & Comparison and Contrast \\
\hline
\end{tabular}

With the CBI course, Financial Markets, introduced as a favorable supplement to the regular General English courses, students can make great progress in lecture understanding. In each CBI lesson with the dual emphasis on both content learning and listening comprehension training, particular stress was laid on how to form bridge between content and language. Knowledge relationships such as cause and effect, comparison, classification, hypothesis, and definition played a vital role in bettering the ability of catching discourse markers and comprehend logical relationships in English lecture. After systemically training, students will make great progress in listening comprehension by paying attention to logical relationships in between lines. What's more, students learn the language as a means to understand content rather than as an end in itself and thus the CBI course responds to students' needs and interests. Finally, the relaxed learning atmosphere and cooperative learning give students the support needed for greater self-confidence and higher motivation. Therefore students are more willing to involved and put more effort in learning.

\section{Problems Affecting the Implementation of the CBI Course}

The above study provides an example of how CBI can be embedded within the existing College English curricula especially in most of the ordinary colleges and universities where General English completely dominates the first two-year College English teaching. There still exist several problems affecting the implementation of the CBI course.

The biggest problem which lies ahead is that most language teachers are lack of specific knowledge especially in science, mathematics, and social studies. As is mentioned in Song's thesis (2007), the qualification of language teacher is one of the biggest challenges $\mathrm{CBI}$ is face with. Without months or 
year long learning and training, it is almost impossible for English teacher be qualified for and be competent at subject matter teaching.

Successful CBI courses will take place only through sustained collaboration between language teachers and content instructors. However, in reality the cooperation is almost impossible for teachers from different departments where communication barely occurs. Besides, without administrative support, such time-consuming and demanding job of curriculum planning will keep away those who are willing to try new teaching approaches.

\section{Solutions to the Problems}

A variation on the adjunct approach---team-teaching approach provides a solution to the problem. In this model, language teacher conducted the lesson together with the virtual lecturer. All the tough problems like to elicit subject matter knowledge from students can be shared with the lecturer. The language teacher serves as an assistant teacher, a facilitator, a class-activity organizer and even a learner.

What's more, students are also the resources for information to be consulted. It is especially true in CBI lessons, because students have more academic knowledge than language teachers. Many English language teachers worry about using CBI materials because they feel they don't have the background knowledge of the subject. Although this may well be true to some extent, it is important to remember that the material is only a vehicle for the language. The teacher does not need to know everything and there always is room for the teacher to learn as they teach. Sometimes the best lessons are when you are exploring things together with your students.

As for second problem mentioned above, language teacher working with the open-course lecturer will solve the problem to some extent in the way that professor of the open course dealt with content explaining and language teacher was responsible for adapting the course in terms of linguistic input and activity design. As a result the Chinese content instructor in real world only needs to work with language teacher on the design of course objectives and syllabus before the course commences, which as a consequence saves the content instructor lot of time and labor.

\section{Summary}

The innovation of College English curriculum is essential to College English teaching, however, curricular innovation and research in this area is still sparsely limited in China. The widespread implementation of CBI courses in China is in desperate need of curriculum and course designers and materials developers. Moreover, since CBI is proved to be an effective way of integrating content learning with language acquisition, a longer time is expected in colleges and universities with the administrative support for CBI philosophy and application.

\section{Acknowledgements}

Wuhan Polytechnic University School-level Teaching and Research Fund Project: "Study on the Training Model of Innovative Students in College English Teaching under the Guidance of the Cultivation mode of 2018 Edition"(No,XZ2018006,2018)

\section{References}

[1]Brinton, D.M., Snow, M.A.,\&Wesche, M. 2003. Content-Based Second Language Instruction 20d ed. Ann Arbor, MI: University of Michigan Press.

[2]Cai Jigang, 2014, A Subversive Foreign Language Teaching Concepts and Methods : Differential Study of Academic English and College English.[J].Foreign Language Learning Theory and Practice.2: 1-7.

[3]Cai Jigang, 2012a, Reflections on the Repositioning of College English in China.[J].Foreign Language Teaching and Research. No.4, 306-308. 
[4]Kong Stella. 2009. Content-Based Instruction: What Can We Learn from Content-Trained Teachers' and Language-Trained Teachers' Pedagogies? Canadian Modern Language Review, 66 (2), pp.233-267.

[5]Lv Xiaojuan, Yang Yue, 2008, Research on the Application of Theme Mode in Basic English Teaching.[J].Journal of Xi'an International Studies University. No.3,84-86.

[6]Song Jie, 2007, A Study of Integrating Content-Based Instruction into Foundation Stage College English Major Course Systems.[D].Dalian University of Foreign Languages.

[7]Yang Huizhong, 2012, Thought about College English Teaching.Foreign Language Teaching Research(bimont hly).Vol (44), 2: 293-297.

[8]Yuan Pinghua,Yu Liming, 2008, A Study on the Teaching Mode of Foreign Languages in University Based on Content. [J].Foreign Language Teaching and Research. No.1,59-64.

[9]Yuan Pinghua, 2008, A Study on Content-based Instruction in the Chinese College English Context. [D].Shanghai Jiao Tong University

[10]Xie Deqiong, 2005, On the Personalized College English Curriculum.[J].Journal of Southwest Agricultural University.No.4,133-136. 